\title{
Dumpingsyndrom etter kirurgi på magesekken
}

\begin{abstract}
BAKGRUNN Dumpingsyndrom er betegnelsen på et vanlig symptombilde etter kirurgi på magesekken, og karakteriseres av postprandialt ubehag som kan medføre ernæringsproblemer. Tilstanden var godt kjent da kirurgi var vanlig behandling av peptisk ulcussykdom. Et stadig økende antall operasjoner for sykelig overvekt medfører at tilstanden igjen er aktuell, og helsepersonell vil møte disse pasientene i ulike sammenhenger. Vi redegjør i denne artikkelen for forekomst, symptomatologi og behandling.
\end{abstract}

KUNNSKAPSGRUNNLAG Oversiktsartikkelen er basert på et utvalg av artikler fra PubMed som er vurdert til å ha særlig relevans for å belyse problemstillingen, samt forfatternes egne kliniske erfaringer.

RESULTATER Tidlig dumpingsyndrom kommer gjerne innen 15 minutter etter et måltid og skyldes rask tilførsel av mat til tynntarmen. Kvalme, abdominalsmerter, diaré, varmefølelse, svimmelhet, blodtrykksfall og hjertebank er typiske symptomer. Slapphet og søvnighet etter måltid er vanlig. Sent dumpingsyndrom kan skyldes hypoglykemi, med tremor, kaldsvette, konsentrasjonsvansker og bevissthetstap. Dumpingrelaterte plager forekommer hos $20-50 \%$ etter kirurgi på magesekken. Tidlig dumpingsyndrom er vanligere enn sent dumpingsyndrom. Anslagsvis 10-20\% har uttalte symptomer og 1-5\% alvorlige symptomer. Diagnosen stilles vanligvis på basis av typiske symptomer. De fleste opplever symptomlindring over tid og ved endringer i kost og spisevaner. Ytterligere utredning og medikamentell eller kirurgisk intervensjon kan være aktuelt for enkelte.

FORTOLKNING Dumpingrelaterte plager er vanlig etter kirurgi på magesekken. Det store omfanget av spesielt fedmekirurgi gjør at helsepersonell bør ha kunnskap om tilstanden.

Dumpingsyndrom er blant de vanligste plagene etter kirurgi på magesekken og karakteriseres ved et typisk postprandialt symptombilde med ubehag, ernæringsproblemer og vekttap (1). Sammenhengen mellom postprandiale symptomer og rask tømming av magesekken etter ventrikkelkirurgi ble beskrevet i 1913 (2). Begrepet «dumping» ble introdusert i 1920 hos pasienter etter gastrektomi (3).

Ventrikkelkirurgi inkluderer blant annet behandling av kreft i mage, spiserør og bukspyttkjertel, gastroøsofageal reflukssykdom og sykelig fedme. Operativ behandling av ulcussykdom var tidligere vanlig årsak til dumpingsyndrom, men utføres nå sjelden. Det opereres omkring 250 pasienter årlig med kurativ intensjon for kreft i spiserør og magesekk i Norge. Fedmekirurgi er imidlertid den vanligste årsaken til dumpingsyndrom i dag. Antallet som opereres for sykelig fedme har vært økende siden 2004 og utgjør nå ca. 3000 pasienter årlig i Norge. Anslagsvis $3 / 4$ av disse opereres med gastrisk bypass.

Samlet omfatter disse inngrepene et betydelig antall pasienter. Med bakgrunn i våre erfaringer, spesielt med pasienter som er operert for sykelig fedme, ønsker vi med denne artikkelen å beskrive fenomenet dumpingsyndrom og diagnostikk og behandling av tilstanden, da helsepersonell vil møte disse pasientene i ulike sammenhenger.

\section{Kunnskapsgrunnlag}

Vi søkte etter engelsk- og norskspråklige original- og oversiktsartikler i PubMed med bruk av søkekombinasjoner som «dumping», «dumping syndrome», «dumping and gastrointestinal surgery», «dumping and gastrectomy», og "dumping and bariatric surgery». Det ble ikke gjort begrensninger bakover i tid. Sammendrag og/eller hele artikler identifisert ved bruk av søkekombinasjonene ble evaluert. Vi inkluderte artikler som vi vurderte som særlig relevant for beskrivelse av forekomst, symptomatologi og behandling. Vi har også med egne kliniske erfaringer fra pasientgruppen.

\section{Symptombilde}

Dumpingsyndrom omfatter typiske symptomer i forbindelse med og etter inntak av føde (tab 1) (4). Symptombildet inndeles ofte i «tidlig dumpingsyndrom» og «sent dumpingsyndrom». Enkelte pasienter har begge former (1). Plagene forekommer normalt ikke ved faste, og intensiteten av symptomene kan graderes $(5,6)$.

Symptomer på tidlig dumpingsyndrom kommer gjerne under måltidet eller like etterpå, typisk innen 15 minutter, og varer inntil 20-30 minutter for så å avta (5). Plagene kan være særlig uttalte etter raske og store måltider. Særlig synes dette å gjelde karbohydratrike måltider. Kvalme, luftplager, abdominalkramper, smerter, og (eksplo-

\author{
Tom Mala \\ tom.mala@netcom.no \\ Senter for sykelig overvekt i Helse Sør-Øst \\ og \\ Avdeling for gastro - og barnekirurgi \\ Oslo universitetssykehus \\ Stephen Hewitt \\ Ingvild Kristine Dahl Høgestøl \\ Senter for sykelig overvekt i Helse Sør-Øst \\ og \\ Institutt for klinisk medisin \\ Universitetet i Oslo \\ Kristin Kjellevold \\ Avdeling for gastro - og barnekirurgi \\ Oslo universitetssykehus \\ Jon A. Kristinsson \\ Senter for sykelig overvekt i Helse Sør-Øst \\ Hilde Risstad \\ Senter for sykelig overvekt i Helse Sør-Øst \\ og \\ Institutt for klinisk medisin \\ Universitetet i Oslo
}

Se også kunnskapsprøve

på www.tidsskriftet.no/quiz

HOVEDBUDSKAP

Dumpingsyndrom forekommer hyppig etter kirurgi på magesekken

Symptomene håndteres vanligvis av pasientene selv etter kostveiledning og avtar med tiden

For noen er plagene uttalte og profesjonell hjelp er nødvendig

Oppfølging av vektutvikling, ernæring og eventuelle mangeltilstander anbefales 
Tabell 1 Diagnostisk poengsystem for evaluering av symptomer relatert til dumpingsyndrom (4). 7 poeng eller mer etter et testmåltid antyder at syndromet foreligger

\begin{tabular}{lc}
\hline Sjokk/presjokk & +5 \\
Følelse av å ville besvime, & +4 \\
synkope, bevisstløshet & +4 \\
Ønske om å legge seg/sette seg & +3 \\
Tungpustethet & +3 \\
Svekkelse, utmattelse & +3 \\
Tretthet, slapphet, gjesping, & +3 \\
apati, det å falle i søvn & +2 \\
Hjertebank & +2 \\
Rastløshet & +1 \\
Svimmelhet & +1 \\
Hodepine & +1 \\
Varmefølelse, svette, blekhet, & +1 \\
klam hud & +1 \\
Kvalme & -1 \\
Metthet & -4 \\
Rumling i magen/luftplager & \\
Raping & +1 \\
Oppkast & \\
\hline
\end{tabular}

siv) diaré er vanlige gastrointestinale symptomer, mens rødme, varmefølelse, svimmelhet, blodtrykksfall og økt hjertefrekvens (hjertebank) kan være typiske vasomotoriske reaksjoner. Mange opplever symptomlindring ved å legge seg ned $(5,6)$.

Sent dumpingsyndrom kommer som oftest 1-3 timer etter måltid og karakteriseres av symptomer som skjelvinger, kaldsvette, sultfølelse, konsentrasjonsvansker og forvirring $(1,7)$. Plagene kan forsterkes av fysisk aktivitet og når det går lenge mellom måltider. Slike symptomer skyldes gjerne postprandial hypoglykemi. Alvorlige symptomer som svimmelhet, synsforstyrrelser, kognitiv affeksjon, svekket bevissthet, besvimelse og kramper er beskrevet etter både gastrektomi og fedmekirurgi $(8,9)$. Det skjer vanligvis ved plasmaglukoseverdier $<3,0 \mathrm{mmol} / \mathrm{l}$ (10). I en svensk studie var sannsynligheten for hypoglykemi, konfusjon, synkope og kramper større etter gastrisk bypass sammenliknet med en referansepopulasjon (8).

For begge varianter vil de fleste oppleve symptomlindring ved å unngå eller redusere mengden av mat som utløser symptomer (1, 11). Enkelte reduserer imidlertid næringsinntaket i for stor grad for å minske plagene (sitofobi) (1). Dumpingrelaterte plager kan ha sosiale konsekvenser blant annet ved at pasientene helst spiser hjemme (11).

\section{Forekomst}

Angivelse av forekomsten av dumpingsyndrom varierer betydelig. I de fleste oversiktsartikler beskrives dumpingrelaterte symptomer hos $20-50 \%$ av pasientene etter kirurgi på magesekken (11-13). I enkeltstående studier angis at $4-75 \%$ opplever dumpingsyndrom etter reseksjon av magesekk og spiserør, og kvinnelig kjønn og ung alder er risikofaktorer (14-17). Når i forløpet etter kirurgi tilstanden blir evaluert, synes å være av betydning, idet mange pasienter opplever bedring med tiden $(1,12)$. Dumpingrelaterte plager er beskrevet hos $75 \%$ av pasientene det første året etter spiserørsreseksjon og hos hver tredje pasient mer enn ti år etter operasjonen $(17,18)$. Pasientene lærer trolig med tiden å håndtere symptomene eller å unngå mat som utløser disse (18). I en evaluering av 1153 pasienter $1 / 2-5$ år etter ventrikkelreseksjon hadde $68 \%$ symptomer på tidlig dumpingsyndrom og $38 \%$ sent dumpingsyndrom (19). I denne studien fant man imidlertid at forekomsten var lik hos pasienter med mindre enn to års observasjonstid og pasienter med mer enn tre års observasjonstid etter kirurgi (19).

De vanligste inngrepene for sykelig fedme i Norge er gastrisk bypass og langsgående ventrikkelreseksjon (gastric sleeve). Forekomsten av dumpingsyndrom varierer også betydelig etter fedmekirurgi og angis å være ca. $20-75 \%$ blant dem som har fått utført gastrisk bypass (20-22). I en studie to år etter gastrisk bypass hadde $12 \%$ av pasientene uttalte symptomer hovedsakelig i form av postprandial slapphet og behov for å legge seg, $7 \%$ hadde mye problemer med kvalme og $6 \%$ følelse av å ville besvime (7). Symptomer på dumping er beskrevet hos omkring 30\% det første året etter langsgående ventrikkelreseksjon, men dokumentasjonen er svakere enn for gastrisk bypass $(23,24)$.

I en norsk studie av 241 pasienter operert med ventrikkelreseksjon for ulcussykdom fant man at $34 \%$ hadde dumpingsyndrom $1-10$ år etter operasjonen, hvorav $14 \%$ hadde daglige plager (16). Tilstanden forekommer også etter fundoplikasjon, spesielt hos barn, og andre inngrep på og nær magesekken (25).

Selv om dumpingsyndrom er vanlig, opplever de fleste pasientene milde symptomer som bedres med tiden (17-19). Plagene kan imidlertid være uttalte hos $10-20 \%$ av pasientene, og 1-5\% vil kunne utvikle alvorlige symptomer $(1,12,16,26)$. Tidlig dumpingsyndrom er vanligere enn sent, med fordelingen ca. $75 \%$ versus $25 \%$ av pasientene $(1,12,19)$.

\section{Patofysiologi}

Patogenesen er ikke fullstendig klarlagt. Sentralt i forståelsen av tidlig dumpingsyndrom er en hurtig passasje av ufordøyd tarminnhold til tynntarmen. Det kan skje etter reseksjon eller forbikobling av pylorus, men også ved endringer i magesekkens tømningshastighet. Endringer i magesekkens reservoarfunksjon og vagusskade kan være medvirkende til dumpingsyndrom etter reseksjon av spiserøret (14). Normalt starter ventrikkelen fordøyelsesprosessen og leder produktene porsjonsvis videre.

Ved tidlig dumpingsyndrom antas føden å ha en osmotisk effekt som bidrar til væskeskifte til tarmlumen med påfølgende tarmdistensjon, noe som kan forklare symptomer som abdominalsmerter (fig 1) (1). Tilsvarende vil dette væskeskiftet fra blod til tarm kunne medføre en økning i hematokrit og fall i plasmavolum (11). Dette kan være fysiologiske mekanismer bak symptomer som takykardi og svimmelhet. Hormoner og peptider som nevrotensin, serotonin, bradykinin, motilin og vasoaktivt intestinalt polypeptid er trolig også involvert i tidlig dumpingsyndrom. Dette kan skyldes modifisert fysiologisk respons på næringstilførsel på grunn av endringer i anatomien $(1,11,13)$. Disse har innvirkning på gastrointestinal motilitet og sekresjon og kan også ha hemodynamiske effekter som hemokonsentrasjon, vasodilatasjon av splanchnicusgebetet og hypotensjon (13).

Sent dumpingsyndrom antas å skyldes rask absorpsjon av karbohydrater som medfører en kraftigere insulinrespons enn den tilsvarende responsen ved intravenøs tilførsel av glukose, kalt «inkretineffekten» (fig 1). Denne insulinresponsen kan medføre hypoglykemi (blodsukker $\leq 3,9 \mathrm{mmol} / \mathrm{l}$ ). De fleste uten diabetes får først symptomer ved lavere verdier, men terskelen for symptomgivende hypoglykemi er individuell (10).

Inkretinhormonet glukagonliknende peptid-1 (GLP-1) kan være medvirkende i utviklingen av hypoglykemi, men mekanismene er ikke fullt klarlagt (13). Det er vist forsterket GLP-1-respons av glukosetestmåltid etter reseksjon av spiserør og ventrikkel (11). Hemming av GLP-1-reseptor hos pasienter med gastrisk bypass og postprandial hypoglykemi reduserer forekomsten av hypoglykemi og symptomer på sent dumpingsyndrom (27). Nesidioblastose er en sjelden tilstand med øycellehyperplasi i pancreas med økt insulinproduksjon. Tilstanden er beskrevet blant annet etter gastrisk bypass og ventrikkelreseksjon, og synes ofte, i motsetning til dumpingsyndrom, å oppstå flere år etter kirurgi $(9,28)$.

\section{Diagnostikk}

Diagnostikken er basert på tilstedeværelse av typiske symptomer etter matinntak. 


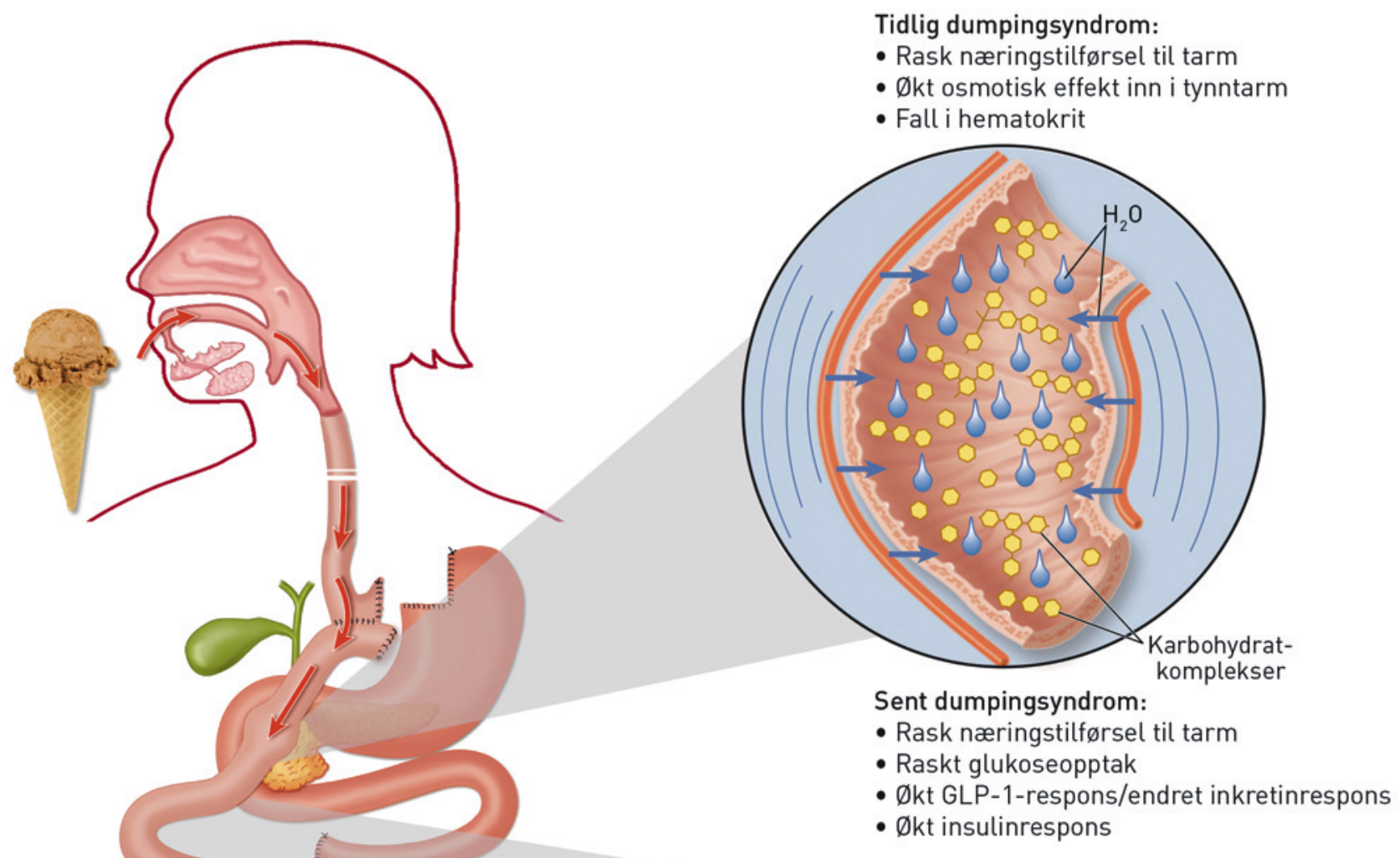

Tidlig dumpingsyndrom

Rask næringstilførsel til tarm

inn i tynntarm
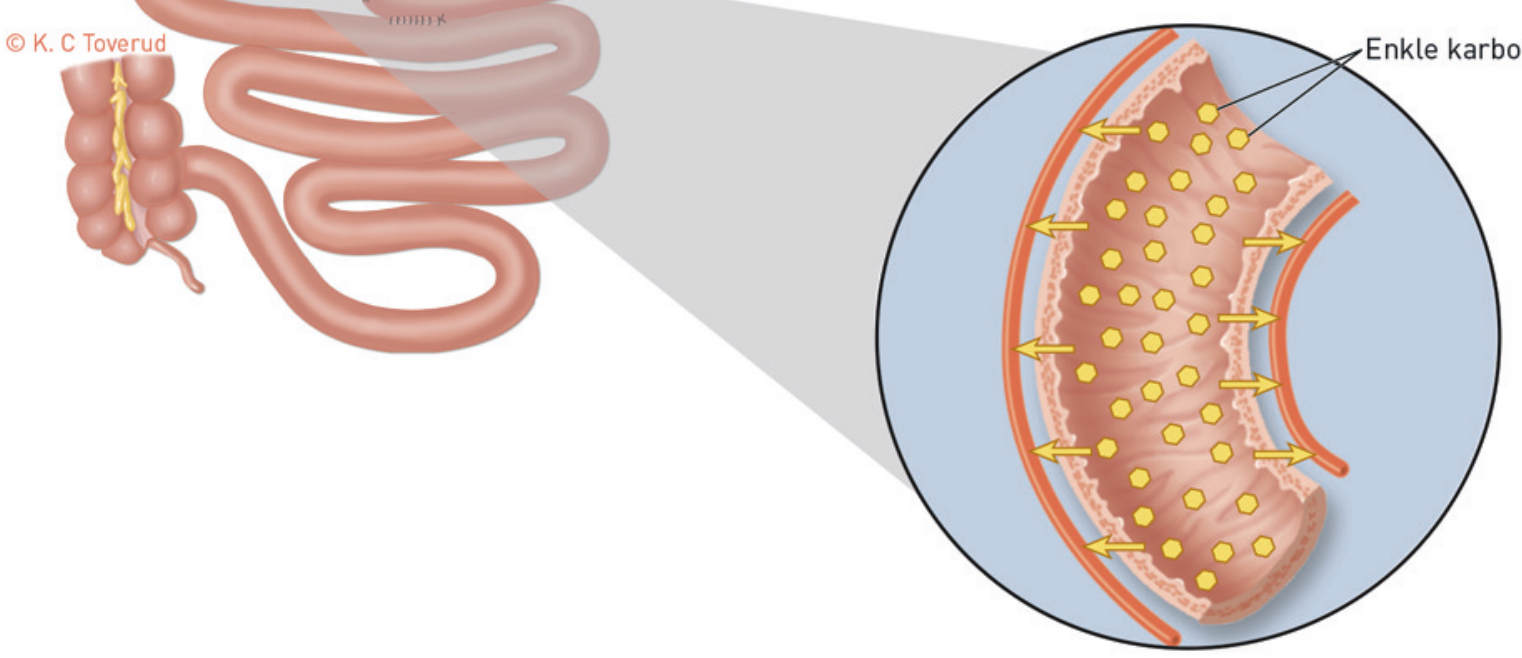

Figur 1 Skjematisk fremstilling av dumpingsyndrom etter gastrisk bypass. Den røde pilen indikerer hurtig passasje av næring og spesielt raske karbohydrater til tynntarmen. Dette medfører en osmotisk effekt av bl.a. karbohydratkomplekser som trekker væske til tarmen med påfølgende dilatasjon av tarm, fall i plasmavolum og symptomer på tidlig dumpingsyndrom. Symptomer på sen dumping illustreres med raskt opptak av enkle karbohydrater med blant annet påfølgende økt inkretin og insulinrespons

Helge Sigstad beskrev i 1970 en diagnostisk indeks som benyttes i beskrivelsen av dumpingsyndrom og i vurderingen av terapeutisk respons (tab 1) (4). En indeks på minst 7 etter et testmåltid antyder at syndromet foreligger. Det finnes også andre skjemaer som kan brukes til å identifisere pasienter med dumpingsyndrom (7).

En oral provokasjonstest (glukoseløsning) etter faste kan benyttes i diagnostikken. Blodtrykk, puls, serum-glukose og hematokrit registreres før og med 30 minut- ters intervaller etter testen. Testen er positiv dersom hematokrit øker mer enn $3 \%$, pulsen øker minst 10 slag i minuttet eller dersom hypoglykemi tilkommer (11-13). Økningen i puls den første timen etter testen har høy sensitivitet (100\%) og spesifisitet (92\%) for tidlig dumpingsyndrom $(11,12)$. Hydrogenpustetest etter oralt glukoseinntak og undersøkelse av magesekkens tømningshastighet kan benyttes, men den diagnostiske treffsikkerheten synes mer usikker $(11-13,29,30)$.

Hypoglykemi som årsak til postprandiale symptomer sannsynliggjøres ved bruk av Whipples triade. Den består av symptomer og/eller tegn på hypoglykemi, samtidig lave plasma-glukoseverdier og bedring av symptomene når plasma-glukoseverdiene normaliseres $(10,31)$. Ved mistanke om symptomgivende hypoglykemi bør man henvise til spesialisthelsetjenesten for nærmere utredning.

Tilkommer dumpingliknende gastrointestinale symptomer lang tid etter kirurgi, bør man vurdere annen årsaksforklaring, idet 


\section{RAMME 1}

Kostholdsråd for pasienter med symptomer på tidlig og sent dumpingsyndrom etter kirurgi på magesekken. Rådene baseres på oversiktsartikler som angitt i referanselisten (11-13) og forfatternes erfaringer med pasientene. Klinisk ernæringsfysiologer ved Senter for sykelig overvekt, Oslo universitetssykehus er også konsultert angående kostholdsrådene

- Bruk tid på måltidet, tygg maten godt. Unngå stressende spisesituasjoner, tilrettelegg for matro.

Regelmessige, små måltider (2-3 timers mellomrom).

Vent ca. 30 minutter med væskeinntak etter matinntak.

Mat før/under fysisk aktivitet kan motvirke plager under aktivitet.

- Innta «langsomme» karbohydrater (mat med lav glykemisk indeks), f.eks. grove kornprodukter og grønnsaker. Unngå «raske» karbohydrater (raffinerte kornvarer og matvarer tilsatt sukker) samt drikke som juice, melk og drikker tilsatt sukker.

- Å erstatte «raske» karbohydrater med proteinrik mat og tungt fordøyelige karbohydrater («langsomme» karbohydrater/ fiber) motvirker svingninger med lavt blodsukker.

Ha mat lett tilgjengelig ved anfall av hypoglykemi.

- Unngå alkohol eller reduser inntaket.

- Den totale mengden karbohydrater i kosten bør begrenses dersom man ikke kommer i mål med ovennevnte tiltak.

tidlig dumping vanligvis oppstår etter kort tid (11). Kontrastundersøkelser og gastroskopi kan da være aktuelt (1).

\section{Behandling}

Mekanismene for tidlig og sent dumpingsyndrom er forskjellige, og den terapeutiske tilnærmingen er derfor ulik. De fleste pasientene responderer tilfredsstillende på endringer i diett og spisevaner $(11-13)$. Ved den tidlige varianten anbefales hyppige små og tørre måltid der man venter med å drikke (ramme 1). Enkle sukkerforbindelser bør unngås, mens andelen komplekse karbohydrater, fiber og proteiner bør økes. Melkeprodukter tolereres ofte dårlig, også enkelte kjøttprodukter (11). Mange anbefaler at man reduserer eller unngår inntaket av alkohol. Et adekvat kaloriinntak kan sikres ved å øke fettandelen $(1,11,12)$. $\AA$ legge seg etter måltid kan gi symptomlindring for pasienter som blir søvnige, trette og slappe (13).

Kostfiber og komplekse karbohydrater kan forsinke opptaket av glukose, gi en langsommere insulinrespons og dermed bedre symptomene på sent dumpingsyndrom (ramme 1) (13). Som oftest foreligger forvarsler på sent dumpingsyndrom og hypoglykemi, og det er viktig å bevisstgjøre pasientene på symptomene og gi råd om å ha mat tilgjengelig, noe som kan være god symptomlindrende behandling for mange med sent dumpingsyndrom.

Medikamentet akarbose (alfaglykosidasehydrolase-inhibitor) kan ha effekt på sent dumpingsyndrom ved å hemme eller forsinke nedbrytningen av karbohydratforbindelser og dermed opptak av glukose. Bivirkninger er malabsorpsjon, flatulens og diaré $(1,12,13)$. Oktreotid (somatostatinanalog) kan i sjeldne tilfeller gi symptomlindring både ved tidlig og sent dumpingsyndrom $(6,11-13)$. Diazoksid har vært benyttet $\mathrm{i}$ behandlingen av hypoglykemi hos enkelte (13).

Kirurgi vurderes unntaksvis dersom andre tiltak er utprøvd i lengre tid uten tilfredsstillende effekt. Gastrisk bypass har vært reversert til «vanlig» anatomi, og etter ventrikkelreseksjon har man konvertert til alternative former for gastrointestinal rekonstruksjon $(12,32)$. I behandlingen av refraktær hypoglykemi har pancreasreseksjon vært benyttet (13). Dokumentasjonen av effekt er sparsom.

\section{Diskusjon}

Antallet pasienter som gjennomgår kirurgi som kan medføre dumpingsyndrom har økt betydelig de siste årene og skyldes i stor grad bruken av fedmekirurgi siden 2004. Symptomer som tidligere var relatert til kreft - og ulcuskirurgi ses nå også i en annen stor og ofte ung pasientgruppe. Dumpingsyndrom ble beskrevet i Tidsskriftet i 1967 da kirurgisk behandling av ventrikkelog duodenalsår var vanlig (5). Omfanget av fedmekirurgi aktualiserer ny oppmerksomhet mot dumpingrelaterte symptomer og plager.

Årsaken til at forekomsten av dumpingsyndrom varierer så mye, er sammensatt og inkluderer kirurgisk teknikk, systematikk i pasientoppfølgingen og metodene og definisjonene som benyttes $\mathrm{i}$ evalueringen av symptomene $(16,22)$. Om man tar med lette symptomer eller kun uttalte plager, og når i forløpet etter operasjonen pasientene evalueres, har betydning. Det bør tilstrebes reproduserbare kriterier for definisjon og gradering av symptomenes intensitet samt objektive effektmål av intervensjon $(6,16)$.

Dumpingrelaterte plager kan gi uønsket vekttap, feilernæring og helseskade. Infor- masjon om symptomene og behandlingen gjør at pasientene kan kjenne igjen disse og ofte med enkle grep selv kunne håndtere dem (7). Dette er også vår erfaring når pasientene som opereres for sykelig fedme får informasjon gjennom preoperativ kursing og postoperativ oppfølging. Fokus på plagene og ernæringsstatus kan ha betydning for livskvalitet og redusere risiko for senbivirkninger $(6,17)$. Plagene kan bidra til endrede matpreferanser, og det er et viktig mål i oppfølgingen å sikre et næringsrikt kosthold. Pasienter som har vansker med å håndtere situasjonen bør få tilbud om oppfølging hos ernæringsfysiolog og/eller lege.

Dumpingsyndrom har vært sett på som en mulig forklaring på vekttapet etter fedmekirurgi, men enkelte finner ikke det som en avgjørende faktor etter gastrisk bypass (7, $21,22)$. På den annen side er vekttap etter gastrektomi assosiert med både tidlig og sent dumpingsyndrom (19).

Vi har opplevd pasienter med plagsom hypoglykemi etter fedmekirurgi og ser da ofte pasientene registrere glukoseverdier under $3 \mathrm{mmol} / \mathrm{l}$ ved symptomer. Tilsvarende er beskrevet også etter annen ventrikkelkirurgi (9). Typisk for våre pasienter er at de har hatt forvarsler. God veiledning er derfor viktig for å forebygge alvorlig hypoglykemi. Manglende kontroll ved anfall kan få konsekvenser for førerkort. Pasienter med symptomer som gir mistanke om hypoglykemi og som ikke responderer på kostendringer, eller pasienter med symptomer fra sentralnervesystemet som kramper og endret bevissthet, skal henvises for utredning og oppfølging i spesialisthelsetjenesten.

Oppsummert forekommer dumpingrelaterte plager hyppig. Fedmekirurgi og operasjoner på spiserør og magesekk er blant de vanligste årsakene. Symptomene beskrives som tidlige eller sene og avtar ofte ved kostveiledning eller over tid. Noen har vedvarende plager og enkelte har behov for hjelp. Symptomer på hypoglykemi kan kreve utredning i spesialisthelsetjenesten. Helsepersonell bør kjenne symptomene og kunne iverksette tiltak og oppfølging med vekt på ernæring og eventuelle mangeltilstander.

Vi ønsker å takke Silje Sæby Dypvik og Lena Aven, begge kliniske ernæringsfysiologer ved Senter for sykelig overvekt, Oslo universitetssykehus, for kommentarer og kritisk gjennomgang av kostholdsrådene i ramme 1 .

\section{Tom Mala (f. 1968)}

er spesialist i generell kirurgi og i gastroenterologisk kirurgi og overlege.

Forfatter har fylt ut ICMJE-skjemaet og oppgir ingen interessekonflikter. 


\section{Stephen Hewitt (f. 1963)}

er spesialist i indremedisin, doktorgradsstipendiat og overlege.

Forfatter har fylt ut ICMJE-skjemaet og oppgir ingen interessekonflikter.

\section{Ingvild Kristine Dahl Høgestøl (f. 1985)}

er lege og doktorgradsstipendiat.

Forfatter har fylt ut ICMJE-skjemaet og oppgir ingen interessekonflikter.

\section{Kristin Kjellevold (f. 1967)}

er spesialist i generell kirurgi og i gastroenterologisk kirurgi og overlege.

Forfatter har fylt ut ICMJE-skjemaet og oppgir ingen interessekonflikter.

\section{Jon A. Kristinsson (f. 1959)}

er spesialist i generell kirurgi og i gastroenterologisk kirurgi, overlege og avdelingsleder. Forfatter har fylt ut ICMJE-skjemaet og oppgir ingen interessekonflikter.

\section{Hilde Risstad (f. 1977)}

er lege i spesialisering og doktorgradsstipendiat.

Forfatter har fylt ut ICMJE-skjemaet og oppgir ingen interessekonflikter.

\section{Litteratur}

1. Carvajal SH, Mulvihill SJ. Postgastrectomy syndromes: dumping and diarrhea. Gastroenterol Clin North Am 1994: 23: 261 - 79.

2. Hertz AF. The cause and treatment of certain unfavourable after-effects of gastroenterostomy. Ann Surg 1913; 58: 466-72

3. Wyllys E, Andrews E, Mix CL. Dumping stomach» and other results of gastrojejunostomy: operative cure by disconnecting old stoma. Surg Clin Chic 1920; 4: 879-92.

4. Sigstad H. A clinical diagnostic index in the diagnosis of the dumping syndrome. Changes in plasma volume and blood sugar after a test meal. Acta Med Scand 1970; 188: 479-86.

5. Gjone E, Sigstad H. Post-gastrektomi syndromer. Tidsskr Nor Lægeforen 1967; 87: 866-8.
6. Arts J, Caenepeel P, Bisschops R et al. Efficacy of the long-acting repeatable formulation of the somatostatin analogue octreotide in postoperative dumping. Clin Gastroenterol Hepatol 2009; 7 432-7.

7. Laurenius A, Olbers T, Näslund I et al. Dumping syndrome following gastric bypass: validation of the dumping symptom rating scale. Obes Surg 2013; 23: 740-55

8. Marsk R, Jonas E, Rasmussen F et al. Nationwide cohort study of post-gastric bypass hypoglycaemia including 5,040 patients undergoing surgery for obesity in 1986-2006 in Sweden. Diabetologia 2010; 53: 2307-11

9. Won JG, Tseng HS, Yang AH et al. Clinical features and morphological characterization of 10 patients with noninsulinoma pancreatogenous hypoglycaemia syndrome (NIPHS). Clin Endocrinol (Oxf) 2006 65: $566-78$

10. Galati SJ, Rayfield EJ. Approach to the patient with postprandial hypoglycemia. Endocr Pract 2014; 20 : $331-40$

11. Vecht J, Masclee AA, Lamers CB. The dumping syndrome. Current insights into pathophysiology. diagnosis and treatment. Scand J Gastroenterol Suppl 1997: 223: $21-7$

12. Ukleja A. Dumping syndrome: pathophysiology and treatment. Nutr Clin Pract 2005; 20: 517-25.

13. Tack J, Arts J, Caenepeel P et al. Pathophysiology, diagnosis and management of postoperative dum ping syndrome. Nat Rev Gastroenterol Hepatol 2009; 6: 583-90

14. Burrows WM. Gastrointestinal function and related problems following esophagectomy. Semin Thorac Cardiovasc Surg 2004: 16: 142-51.

15. Hejazi RA, Patil H, McCallum RW. Dumping syndrome: establishing criteria for diagnosis and identifying new etiologies. Dig Dis Sci 2010; 55: 117-23.

16. Svennevig JL, Vetvik K, Bernstein 0 et al. Dumping following partial gastrectomy. Ann Chir Gynaecol 1977; 66: 4-7

17. Haverkort EB, Binnekade JM, Busch OR et al. Pre sence and persistence of nutrition-related symptoms during the first year following esophagec tomy with gastric tube reconstruction in clinically disease-free patients. World J Surg 2010; 34: 2844-52

18. Greene CL, DeMeester SR, Worrell SG et al. Alimentary satisfaction, gastrointestinal symptoms, and quality of life 10 or more years after esophagectomy with gastric pull-up. J Thorac Cardiovasc Surg 2014: 147: 909-14.

19. Mine S, Sano T, Tsutsumi K et al. Large-scale investigation into dumping syndrome after gastrectomy for gastric cancer. J Am Coll Surg 2010, 211: $628-36$
20. Rostas JW 3rd, Mai TT, Richards WO. Gastric motility physiology and surgical intervention. Surg Clin North Am 2011. 91: 983-99.

21. Mallory GN, Macgregor AM, Rand CS. The influence of dumping on weight loss after gastric restrictive surgery for morbid obesity. Obes Surg 1996; 6: 474-8.

22. Banerjee A, Ding Y, Mikami DJ et al. The role of dumping syndrome in weight loss after gastric bypass surgery. Surg Endosc 2013; 27: 1573-8.

23. Tzovaras G. Papamargaritis D, Sioka E et al. Symptoms suggestive of dumping syndrome after provocation in patients after laparoscopic sleeve gas trectomy. Obes Surg 2012; 22: 23-8

24. Papamargaritis D, Koukoulis G, Sioka E et al. Dumping symptoms and incidence of hypoglycaemia after provocation test at 6 and 12 months after laparoscopic sleeve gastrectomy. Obes Surg 2012 22: $1600-6$

25. Samuk I, Afriat R, Horne T et al. Dumping syndrome following Nissen fundoplication, diagnosis, and treatment. J Pediatr Gastroenterol Nutr 1996 23: $235-40$

26. Li-Ling J, Irving M. Therapeutic value of octreotide for patients with severe dumping syndrome a review of randomised controlled trials. Postgrad Med J 2001; 77: 441-2

27. Salehi M, Gastaldelli A, D'Alessio DA. Blockade of glucagon-like peptide 1 receptor corrects postprandial hypoglycemia after gastric bypass. Gastroenterology 2014; 146: 669-680.e2.

28. Service GJ, Thompson GB, Service FJ et al. Hyperinsulinemic hypoglycemia with nesidioblastosis after gastric-bypass surgery. N Engl J Med 2005. 353: 249-54

29. Cryer PE, Axelrod L, Grossman AB et al. Evaluation and management of adult hypoglycemic disorders: an Endocrine Society Clinical Practice Guideline. J Clin Endocrinol Metab 2009: 94: 709-28.

30. Hammer HF. Medical complications of bariatric surgery: focus on malabsorption and dumping syndrome. Dig Dis 2012; 30: $182-6$.

31. Lipp RW, Schnedl WJ, Hammer HF et al. Evidence of accelerated gastric emptying in longstanding diabetic patients after ingestion of a semisolid meal. J Nucl Med 1997; 38: 814-8.

32. Vilallonga R, van de Vrande S, Himpens J. Laparoscopic reversal of Roux-en-Y gastric bypass into normal anatomy with or without sleeve gastrectomy. Surg Endosc 2013; 27: 4640-8.

Mottatt 15.4. 2014, første revisjon innsendt 22.9. 2014, godkjent 25.11. 2014. Redaktør: Sigurd Høye.

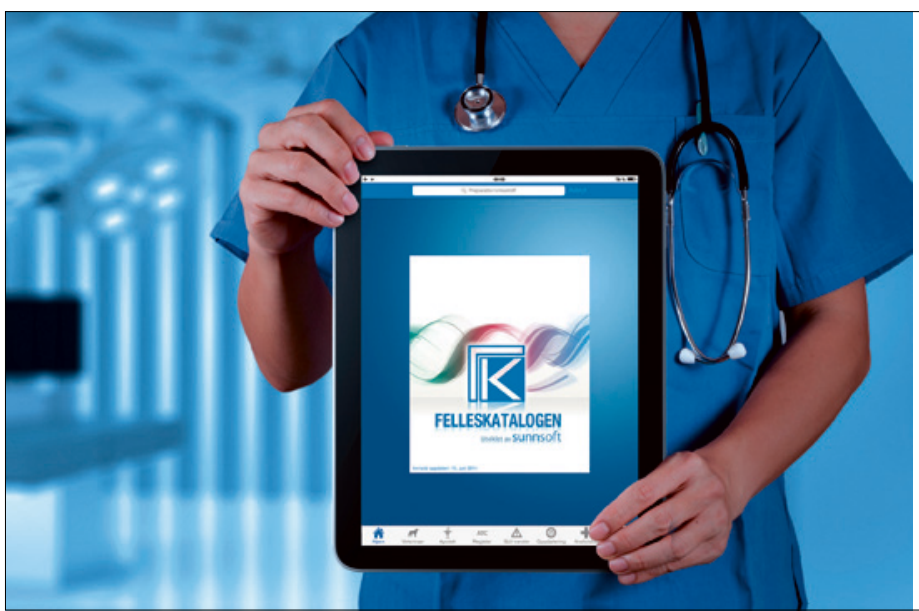

Enkel tilgang til legemiddelinformasjon uten nettilgang

- Felleskatalogen for smarttelefoner og lesebrett 